\title{
Role of technetium-99m diphosphonate and gallium-67 citrate bone scanning in the early diagnosis of infectious spondylodiscitis. A comparative study
}

\author{
Joan Miquel Nolla-Solé, Lourdes Mateo-Soria, Antonio Rozadilla-Sacanell, \\ Jaume Mora-Salvador, José Valverde-García, Daniel Roig-Escofet
}

\begin{abstract}
A comparative study of the parts played by technetium-99m diphosphonate and gallium67 citrate bone scanning in the early diagnosis of infectious spondylodiscitis is presented. Nineteen patients were included in the study. All patients (11 men aged 19-70 years and eight women aged 18-72 years) had a history of back pain varying in duration from one to 15 weeks. A ${ }^{99 m}$ Tc diphosphonate bone scan was positive in 17 patients. The two patients with negative results had less than two weeks of back pain. The ${ }^{67} \mathrm{Ga}$ citrate bone scan showed uptake in all patients.
\end{abstract}

${ }^{99} \mathrm{~m}$ Tc diphosphonate bone scanning is considered to be the most reliable method to establish the early diagnosis of infectious spondylodiscitis. ${ }^{1}$ A normal scan in adults has been used to exclude this diagnosis.

False normal ${ }^{99 \mathrm{~m}} \mathrm{Tc}$ diphosphonate bone scans have been described in children with definite osteomyelitis. ${ }^{2}$ The reason for these normal scans is not clear, but regional ischaemia probably due to thrombosis formation in blood vessels has been suggested. ${ }^{3}$

Schalaeffer et al $^{4}$ have reported two cases of vertebral osteomyelitis in adult patients in whom ${ }^{99} \mathrm{~m}$ Tc diphosphonate bone scans were normal when first performed and became abnormal later in the course of the disease.

${ }^{67} \mathrm{Ga}$ citrate scanning seems to be useful in the diagnosis of osteomyelitis. ${ }^{5}$ At least three mechanisms by which ${ }^{67} \mathrm{Ga}$ might be taken up in infectious regions have been postulated. These include leucocyte labelling, ${ }^{6}$ lactoferrin binding at the side of infection, ${ }^{7}$ and direct bacterial uptake. ${ }^{8}$ Uptake of gallium by bone is less affected by regional blood flow ${ }^{9}$ and theoretically ${ }^{67} \mathrm{Ga}$ citrate scanning could be a good alternative when infectious spondylodiscitis is suggested by strong clinical evidence and the ${ }^{99 \mathrm{~m}} \mathrm{Tc}$ diphosphonate bone scan is normal.

No large comparative studies on the sensitivity of ${ }^{99 \mathrm{~m}} \mathrm{Tc}$ diphosphonate and ${ }^{67} \mathrm{Ga}$ citrate bone scans have been reported. We have evaluated prospectively the value of these scintigraphic techniques in 19 adult patients with microbiologically proved infectious spondylodiscitis.

\section{Patients and methods}

Nineteen consecutive patients with infectious spondylodiscitis determined microbiologically were included in this study.
The same study strategy was followed for all patients. Six days after admission for suspected infectious spondylodiscitis, the following investigations were carried out.

At least four blood cultures were taken. Two or more positive haemocultures were required to accept the diagnosis of infectious spondylodiscitis. Posterior and lateral views of the thoracic and lumbar spine were obtained radiologically. Posterior spine images were obtained two hours after the intravenous administration of $740 \mathrm{MBq}{ }^{99 \mathrm{~m}} \mathrm{Tc}$ diphosphonate. Posterior spine images were obtained 48 hours after the intravenous administration of $100-150 \mathrm{MBq}$ ${ }^{67} \mathrm{Ga}$ citrate. The tracer was administered just after the ${ }^{99 \mathrm{~m}} \mathrm{Tc}$ diphosphonate investigation had finished. A disc biopsy sample was taken when blood cultures were negative and previous investigations supported the diagnosis of infectious spondylodiscitis.

The radiological criteria used for infectious spondylodiscitis were disc space narrowing or irregular erosion of the vertebral endplates adjacent to the disc spaces, or both. The scintigraphic criterion for infectious spondylodiscitis was increased uptake in the vertebral bodies on either side of the affected disc space.

The sensitivity and $95 \%$ confidence intervals were calculated for the radiographic and scintigraphic techniques.

\section{Results}

The table gives the clinical data and results of investigations.

The age of the patients varied between 18 and 72 years. The duration of symptoms before diagnosis varied between one and 12 weeks. All patients had inflammatory back pain and 13 had fever. The erythrocyte sedimentation rate was increased in 18 patients.

Infectious spondylodiscitis was confirmed microbiologically in all cases. Blood cultures were positive in nine patients and a disc biopsy sample was taken in 10 patients. Staphylococcus aureus was the causative agent in seven patients. Mycobacterium tuberculosis in five patients, Proteus mirabilis and Escherichia coli in two patients, and Proteus vulgaris, Pseudomonas aeruginosa and Streptococcus agalactiae in one patient each.

In six patients the conventional radiographs were normal. In all patients with abnormal radiographs the scintigraphic study showed bone uptake. 
Patient profiles. All patients had back pain

\begin{tabular}{|c|c|c|c|c|c|c|c|c|c|c|}
\hline $\begin{array}{l}\text { Patient } \\
\text { No }\end{array}$ & $\begin{array}{l}\text { Age } \\
\text { (years)/ } \\
\text { sex }\end{array}$ & $\begin{array}{l}\text { Duration of } \\
\text { symptoms } \\
\text { (weeks) }\end{array}$ & Disc level & Fever & $\begin{array}{l}E S R \\
(\mathrm{~mm} / \mathrm{h})\end{array}$ & $\begin{array}{l}\text { Microbiological } \\
\text { resultst }\end{array}$ & $\begin{array}{l}\text { Predisposing } \\
\text { factor }\end{array}$ & Radiography & $\begin{array}{l}{ }^{94 m} T c \\
\text { diphos- } \\
\text { phonate } \\
\text { bone scan }\end{array}$ & $\begin{array}{l}{ }^{67} \mathrm{Ga} \\
\text { citrate } \\
\text { bone scan }\end{array}$ \\
\hline 1 & $70 / M$ & 7 & L5-S1 & + & 96 & $\begin{array}{l}\text { Proteus } \\
\text { mirabilis (B) }\end{array}$ & $\begin{array}{l}\text { Diabetes } \\
\text { mellitis }\end{array}$ & + & + & + \\
\hline 2 & $50 / \mathrm{F}$ & 4 & L2-L3 & + & 62 & $\begin{array}{l}\text { Escherichia } \\
\text { coli }(\mathrm{B})\end{array}$ & & + & + & + \\
\hline 3 & $36 / M$ & 1.5 & $\mathrm{~T} 12-\mathrm{Ll}$ & + & 110 & $\begin{array}{l}\text { Siaphylococcus } \\
\text { aureus (D) }\end{array}$ & & - & - & + \\
\hline 4 & $22 / M$ & 3 & L3-L4 & + & 69 & $\begin{array}{l}\text { Siaphylococcus } \\
\text { aureus (B) }\end{array}$ & & + & + & + \\
\hline 5 & $18 / \mathrm{F}$ & 8 & L4-L5 & - & 90 & $\begin{array}{l}\text { Staphylococcus } \\
\text { aureus (D) }\end{array}$ & & + & + & + \\
\hline 6 & $71 / F$ & 10 & L1-L2 & - & 80 & $\begin{array}{l}\text { Proteus } \\
\text { vulgaris (D) }\end{array}$ & & + & + & + \\
\hline 7 & $67 / M$ & 12 & T10-T11 & + & 44 & $\begin{array}{l}\text { Staphylococcus } \\
\text { aureus (B) }\end{array}$ & & - & + & + \\
\hline 8 & $24 / M$ & 1 & L3-L4 & + & 74 & $\begin{array}{l}\text { Staphylococcus } \\
\text { aureus (B) }\end{array}$ & & - & - & + \\
\hline 9 & $19 / M$ & 2 & L2-L3 & + & 63 & $\begin{array}{l}\text { Staphylococcus } \\
\text { aureus (B) }\end{array}$ & & - & + & + \\
\hline 10 & $58 / M$ & 2 & L2-Lì & + & 55 & $\begin{array}{l}\text { Pseudomonas } \\
\text { aeruginosa (B) }\end{array}$ & $\begin{array}{l}\text { Hepatic } \\
\text { cirrhosis }\end{array}$ & + & + & + \\
\hline 11 & $72 / F$ & $2 \cdot 5$ & L5-S1 & + & 120 & $\begin{array}{l}\text { Escherichia } \\
\text { coli (B) }\end{array}$ & $\begin{array}{l}\text { Urinary } \\
\text { infection }\end{array}$ & + & + & + \\
\hline 12 & $58 / \mathrm{F}$ & 8 & T11-T12 & + & 94 & $\begin{array}{l}\text { Proteus } \\
\text { mirabilis (D) }\end{array}$ & & + & + & + \\
\hline 13 & $34 / F$ & $1 \cdot 5$ & L5-S1 & + & 94 & $\begin{array}{l}\text { Streptococcus } \\
\text { agalactiae (D) }\end{array}$ & $\begin{array}{l}\text { SLE treated } \\
\text { with glucocorticoids }\end{array}$ & s & + & + \\
\hline 14 & $21 / M$ & 1 & L5-S1 & + & 52 & $\begin{array}{l}\text { Staphylococcus } \\
\text { aureus (B) }\end{array}$ & & - & + & + \\
\hline 15 & $23 / M$ & 3.5 & T11-T12 & - & 41 & $\begin{array}{l}\text { Mycobacterium } \\
\text { tuberculosis (D) }\end{array}$ & & + & + & + \\
\hline 16 & $28 / M$ & 15 & L2-L3 & - & 32 & $\begin{array}{l}\text { Mycobacterium } \\
\text { tuberculosis (D) }\end{array}$ & Alcoholism & + & + & + \\
\hline 17 & $65 / F$ & 12 & T10-T11 & - & 45 & $\begin{array}{l}\text { Mycobacterium } \\
\text { tuberculosis (D) }\end{array}$ & $\begin{array}{l}\text { Chronic renal } \\
\text { failure }\end{array}$ & + & + & + \\
\hline 18 & $24 / M$ & 8 & L5-S1 & + & 23 & $\begin{array}{l}\text { Mycobacterium } \\
\text { tuberculosis (D) }\end{array}$ & & + & + & + \\
\hline 19 & $72 / F$ & $6 \cdot 5$ & T11-T12 & - & 36 & $\begin{array}{l}\text { Mycobacterium } \\
\text { tuberculosis (D) }\end{array}$ & $\begin{array}{l}\text { RA treated with } \\
\text { glucocorticoids }\end{array}$ & + & + & + \\
\hline
\end{tabular}

${ }^{*}$ ESR = erythrocyte sedimentation rate.

$+B=$ blood culture; $D=$ disc biopsy sample.

${ }^{99 \mathrm{~m}} \mathrm{Tc}$ diphosphonate bone scanning showed bone uptake in 17 patients. The two patients with normal bone scans (patients 3 and 8 ) had a duration of symptoms shorter than two weeks. In both patients a new ${ }^{99 \mathrm{~m}} \mathrm{Tc}$ diphosphonate bone scan repeated six weeks later showed bone uptake. The ${ }^{67} \mathrm{Ga}$ citrate bone scan showed uptake in all patients. Figures 1 and 2 show the results of the two bone scans in patient 8 .
The sensitivity of the ${ }^{6 /} \mathrm{Ga}$ citrate bone scan was unity. The sensitivity of the ${ }^{99 \mathrm{~m}} \mathrm{Tc}$ diphosphonate was 0.89 (95\% confidence interval 0.82 to 0.96$)$. The sensitivity of conventional radiographs was 0.68 (95\% confidence interval 0.67 to 0.69 ).

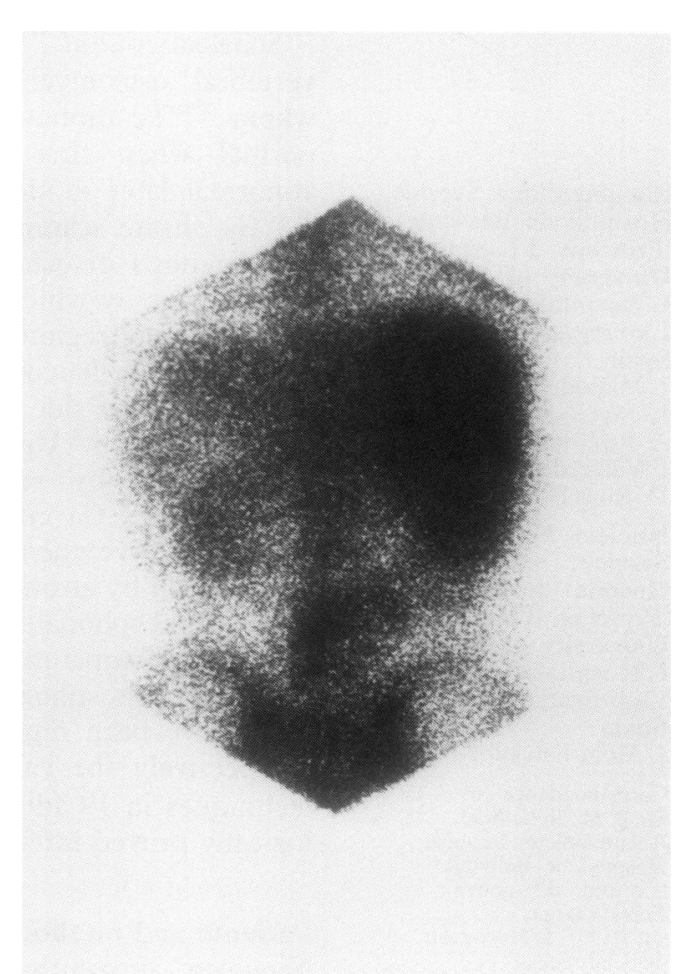

Figure $2{ }^{67} \mathrm{Ga}$ citrate bone scan in patient 8 showing positive uptake (L3-L4 infectious spondylodiscitis).
Figure $1{ }^{99 m} T c$ diphosphonate bone scan in patient 8 showing negative uptake. 


\section{Discussion}

Infectious spondylodiscitis is no longer a rare disease. There has been an increasing incidence of this disease in the last few decades. ${ }^{10}$ Intravenous drug abuse, urinary tract infections, or urinary tract instrumentations and longer life expectations in patients with chronic and debilitating diseases treated with corticosteroids are some of the factors that have contributed to this increase. ${ }^{11}$ Fever and inflammatory back pain are the cardinal clinical features of infectious spondylodiscitis. ${ }^{11}$ Often the signs and symptoms of infection are vague and insidious and therefore the diagnosis may be delayed.

Conventional radiographic studies are not available for the diagnosis of infectious spondylodiscitis. " Radiographic changes do not usually appear until two weeks after infection. ${ }^{99 \mathrm{~m}} \mathrm{Tc}$ diphosphonate bone scanning is a valuable diagnostic procedure for infectious spondylodiscitis. ${ }^{12}$ Early bone uptake, a low radiation burden, high sensitivity, and good imaging resolution are the advantages of this method. ${ }^{5}$

This study supports the value of ${ }^{99 \mathrm{~m}} \mathrm{Tc}$ diphosphonate bone scans in the early diagnosis of infectious spondylodiscitis. Only two patients with infectious spondylodiscitis showed negative bone uptake; this finding was probably due to the absence of bone reaction related to the short duration of their disease. In both patients bone uptake became evident when the ${ }^{99 \mathrm{~m}} \mathrm{Tc}$ diphosphonate bone scan was repeated six weeks after the start of their symptoms.

Our study, however, supports the view that ${ }^{67} \mathrm{Ga}$ citrate scanning is useful in the early diagnosis of infectious spondylodiscitis. The sensitivity of this scintigraphic technique was greater than the ${ }^{99 \mathrm{~m}} \mathrm{Tc}$ diphosphonate bone scan. All patients with infectious spondylodiscitis showed bone uptake of ${ }^{67} \mathrm{Ga}$.

${ }^{67} \mathrm{Ga}$ citrate scanning seems to be useful for the diagnosis of infectious spondylodiscitis even when ${ }^{99 \mathrm{~m}} \mathrm{Tc}$ diphosphonate bone scans are normal. Sullivan et al have previously reported this finding in children. ${ }^{2}$
Dangerous complications that may result from the delay in the diagnosis of infectious spondylodiscitis underline the value of techniques such as ${ }^{99 \mathrm{~m}} \mathrm{Tc}$ diphosphonate and ${ }^{67} \mathrm{Ga}$ citrate bone scanning in early diagnosis. ${ }^{99 \mathrm{~m}} \mathrm{Tc}$ diphosphonate bone scanning is probably the scintigraphic technique of choice because the ${ }^{67} \mathrm{Ga}$ citrate bone scan gives a larger irradiation dose to the patient, a delay of 24 to 48 hours before the results are available, and has poorer imaging resolution. As our study shows, however, in equivocal cases when infectious spondylodiscitis is suspected and the ${ }^{99 \mathrm{~m}} \mathrm{Tc}$ diphosphonate bone scan is normal, ${ }^{67} \mathrm{Ga}$ citrate scanning is a useful alternative diagnostic method. The specificity of this scintigraphic technique should be established in future prospective studies.

1 Nelson H T, Taylor A. Bone scanning in the diagnosis of acute osteomyelitis. Eur F Nucl Med 1980; 5: 267-9.

2 Sullivan D C, Rosenfield N S, Odgen J A, et al. Problems in the scintigraphic detection of osteomyelitis in children. Radiology 1980; 135: 731-6.

3 Odgen J A. Pediatric osteomyelitis and septic arthritis: the pathology of neonatal disease. Yale $\mathcal{F}$ Biol Med 1979; 52: $423-48$

4 Schlaeffer F, Mikovich D J, Mates S. Technetium Tc ${ }^{49 m}$ diphosphonate bone scan. False-normal findings in elderly patients with hematogenous infectious spondylodiscitis. Arch Intern Med 1987; 147: 2024-6.

5 Gupta N C, Prezio J A. Radionuclide imaging in osteomyelitis. Sem Nucl Med 1988; 4: 287-99.

6 Gelrud L G, Arsenan J C, Milder M S, et al. The kinetics of ${ }^{67}$ gallium incorporation into inflammatory lesions: experimental and clinical studies. I Lab Clin Med 1974; 83: 489-95.

7 Wright D G, Pizo P A, Jones A E, et al. Studies of $67 \mathrm{Ga}$ uptake at sites of neutrophil exudation [abstract]. Clin Res 1979; 27: 360A.

8 Menon S, Wagner H N, Tsan M F. Studies of gallium accumulation in inflammatory lesions: II. Uptake by Staphilococcus aureus. Concise communication. $\mathcal{F} \mathrm{Nucl}$ Med 1979; 19: 44-7.

9 Hoffer P. Gallium mechanisms. F Nucl Med 1980; 29: 282-5.

10 Waldvogel F A, Vasey $\mathrm{H}$. Osteomyelitis: the past decade. $N$ Engl f Med 1980; 303: 360-8.

11 Sapico F L, Montgomerie J Z. Pyogenic vertebral osteomyelitis. report of nine cases and review of the literature. Rev Infect Dis 1979; 1754-66.

12 Choong K, Monaghan P, McGuigan L, McLean R. Role of bone scintigraphy in the early diagnosis of discitis. Ann Rheum Dis 1990; 49: 932-4. 